\title{
SOME SOCIAL FACTORS IN PERINATAL MORTALITY
}

\author{
BY \\ D. H. VAUGHAN, M.B., Ch.B., D.P.H. \\ Senior Lecturer, Department of Social and Preventive Medicine, University of Manchester, \\ and the Health Department, City of Salford, Lancashire
}

The infant mortality rate has long been regarded as a useful index of general social conditions, but although secular trends in the rate reflect general social improvements, the gradient in infant mortality from Social Class I to Social Class V has remained virtually unaltered (Titmuss, 1943; Morris and Heady, 1955; Spicer and Lipworth, 1966). Although the perinatal death rate is less obviously related to the extra-uterine environment, this rate also shows sharp variations between the social classes, and these have also remained fairly constant throughout a period of generally falling rates.

Perinatal mortality has been shown to be related closely to maternal age, birth order, and social class as well as to foetal weight (Daly, Heady, and Morris, 1955; Butler and Bonham, 1963) but the interrelations between these variables are themselves complex (Feldstein and Butler, 1965), as are the relevant components of social class itself (Illsley and Kincaid, 1963; Kincaid, 1965).

The importance of the use of services has been illustrated by Hobbs and Acheson (1966), who showed that perinatal mortality was higher in practices where a general practitioner obstetric unit was accessible, and that the proportion of mothers booked for consultant care was reduced by the presence of such a unit and fell further with increasing distance from the consultant unit.

Shegog (1966) has suggested that these considerations warrant studies into perinatal deaths analogous to those carried out into maternal deaths (Ministry of Health, 1966). There is much to be said for this idea even though the numbers involved are large. The kind of social inquiries that would be appropriate seem worth exploring and what follows represents an attempt to isolate some of the relevant social variables.

\section{Subjects AND Methods}

The present study was planned soon after the publication of the report on Perinatal Mortality (Butler and Bonham, 1963) and was designed to examine the position in the County Borough of Salford in greater detail than was possible in a national survey.

Information about stillbirths and infant deaths reaches the health department soon after occurrence, and arrangements were made for all the known facts of the occurrences in 1965 to be made available to a health visitor, who was specially engaged on this study and who later interviewed the mothers. The best timing of the interviews was determined during a pilot study carried out during the last two months of 1964. It was found that, if the mother was seerb 2 weeks after the fatal event, memory was still fresh but recovery from the shock was reasonably complete

A semi-structured interview was used to allow the mother to express herself freely. Discussion ranged widely over the parents' childhood experiences, their education, work, marriage, other children, income, housing, general social background and habits, details of the early weeks of the pregnancy concerned, attitudes to the pregnancy and to antenatal care, attendance at the family doctor, visits to hospital or local authority clinics, mother's recollection of advice at such visits, illnesses during pregnancy, details of the labour, and where appropriate, details of the infant's feeding and progress. Particular attention was paid to the mother's story of the circumstances leading to the death-whether and how she had been prepared for this, and her ideas regarding the causes of the death.

The interviews mostly took place in the families' homes-occasionally in the home of a near relative. In about three-quarters of the cases the mother was alone or with young children; in the others her husband or relatives were present. Each interview lasted about 1-1 $\frac{1}{2}$ hours, the length depending not only on the amount of information the mother was willing and able to give, but on the amount of advice, help, and reassurance she sought at the same time. It is perhaps inevitable that interviews on this subject and in this depth will involve therapy to a greater or lesser degree. 
Interview schedules were completed by the health visitor as soon as she returned to the office. In most cases it was possible to take short notes during the interview.

For many of the factors examined there was no available local standard with which to compare the findings. Information was available about the age and parity of the mothers in the related population and about their place of confinement and social class, but as a control group the mothers of all babies born during the month of October, 1965, and surviving the perinatal period were asked special questions by health visitors during their first visit (usually when the baby was 2 weeks old).

\section{RESULTS}

Table I shows the distribution of mothers in relation to success in interviewing them and reasons for failure. Of the fourteen mothers not interviewed, eleven were under the age of 25 and having their first baby. Apart from the fact that the mothers of four anencephalics (out of a total of fourteen) were not interviewed, it is felt that no serious distortion has occurred because of a failure to interview 12 per cent. of the total.
Cause of Perinatal Death

The registered causes of the stillbirths are given in Table II, and of the first week's deaths in Table III.

TABLE III

REGISTERED CAUSES OF FIRST WEEK DEATHS

\begin{tabular}{l|c|c|c}
\hline \multicolumn{1}{c|}{ Cause } & \multicolumn{3}{|c}{ Number } \\
\cline { 2 - 4 } & Premature & Mature & Total \\
\hline Prematurity & 13 & - & 13 \\
Respiratory distress syndrome & 17 & 3 & 20 \\
Birth injury \\
$\begin{array}{l}\text { Anencephalus } \\
\text { Renal anomaly }\end{array}$ & 3 & 4 & 7 \\
Pneumonia & 2 & $\frac{1}{2}$ & 1 \\
\hline \multicolumn{1}{c|}{ Total } & 4 & - & 4 \\
\hline
\end{tabular}

Premature-5 lb. 8 oz $(2,500$ g. $)$ or less.

The method of classification of these two groups is different and an attempt has been made in Table IV (overleaf) to assess their common background. 'Respiratory Distress Syndrome' has been used to classify a variety of terms such as 'asphyxia' and 'hyaline membrane'. Ten per cent. of the babies who died were born before the end of the 28th week of gestation and 40 per cent. by the 36 th week.

TABLE I

PERINATAL DEATHS, MOTHERS INTERVIEWED, REASONS FOR FAILURE TO INTERVIEW

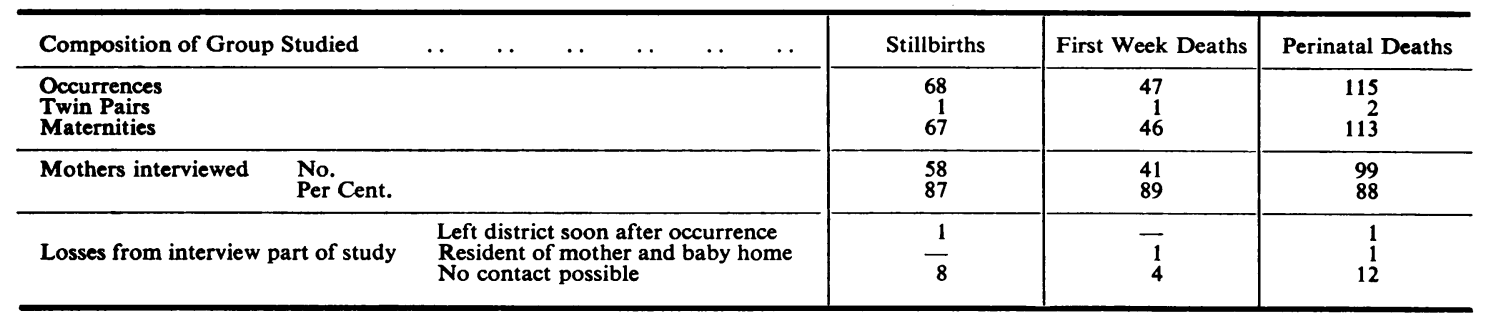

TABLE II

REGISTERED CAUSES OF STILLBIRTH

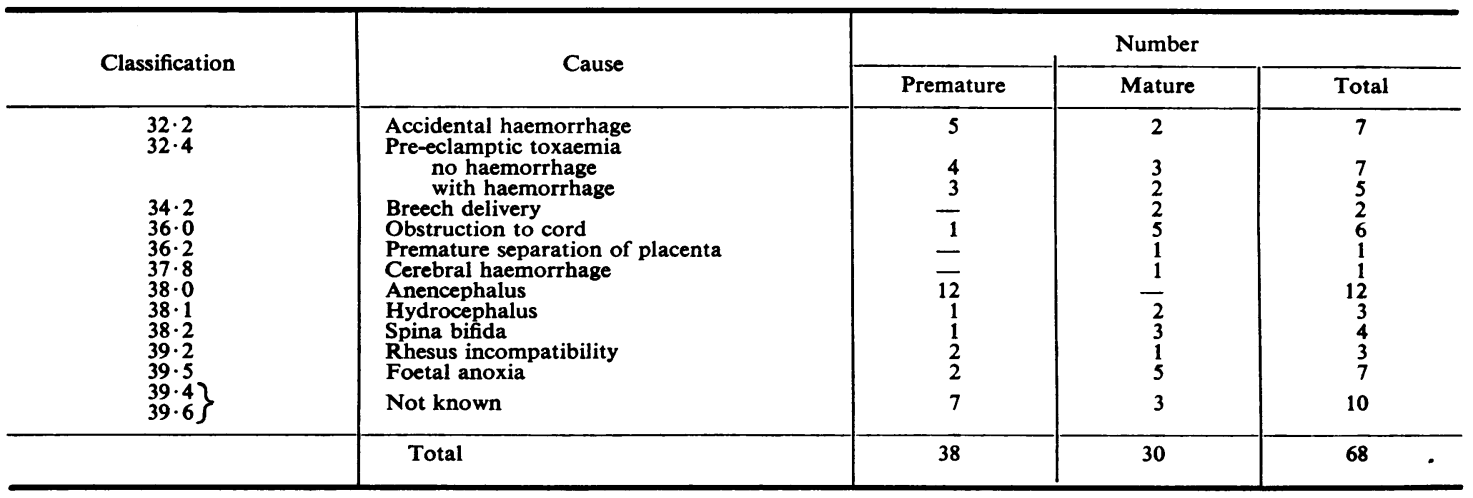


TABLE IV

PERINATAL DEATHS-RELATED MATERNAL AND FOETAL CONDITIONS

\begin{tabular}{|c|c|c|c|c|}
\hline Cause of Death & Stillbirths & First Week Deaths & \multicolumn{2}{|c|}{ Total } \\
\hline $\begin{array}{l}\text { Accidental haemorrhage (no toxaemia) } \\
\text { Toxaemia-no haemorrhage } \\
\text { Breech delivery } \\
\text { Obstruction to cord } \\
\text { Premature separation of placenta } \\
\text { Cerebral haemorrhage } \\
\text { Anencephalus } \\
\text { Hydrocephalus } \\
\text { Spina bifida } \\
\text { Erythroblastosis } \\
\text { Premature labour } \\
\text { Elective caesarian section } \\
\text { Prolonged labour-forceps } \\
\text { Mitral stenosis and forceps } \\
\text { Aspirin poisoning in mother } \\
\text { Foetal anoxia (cause not known) } \\
\text { Unknown }\end{array}$ & $\begin{array}{r}4 \\
7 \\
8 \\
2 \\
6 \\
1 \\
1 \\
12 \\
3 \\
4 \\
3 \\
= \\
= \\
- \\
7 \\
10\end{array}$ & $\begin{array}{r}9 \\
\frac{9}{2} \\
\frac{1}{-} \\
\frac{2}{-} \\
1 \\
20 \\
3 \\
1 \\
1 \\
1 \\
\frac{1}{3}\end{array}$ & $\begin{array}{r}9 \\
8 \\
4 \\
7 \\
1 \\
1 \\
14 \\
3 \\
4 \\
\\
1 \\
1 \\
\\
7\end{array}$ & $\begin{array}{r}13 \\
21 \\
4 \\
20 \\
3 \\
2 \\
1 \\
1 \\
20\end{array}$ \\
\hline Total & 68 & 47 & & 115 \\
\hline
\end{tabular}

\section{Composition of the Control Group}

Table V shows the mother's age, parity, and social class for the study and control groups, for all Salford births and for births in England and Wales for 1965. The control group may reasonably be regarded as representative of all Salford births. Salford mothers are in general younger and have had more previous children than those in England and Wales as a whole.

\section{Mother's Attitude to Ante-natal Care}

In the study group 22 mothers ( 19 per cent.) felt that supervision during the ante-natal period was unnecessary and that as long as a midwife was booked before the delivery nothing more was required (Table VI) ("It's a natural process and you don't need to go if you're well" was a typical observation). Only 7 per cent. of the mothers in the control group took a similar view. This attitude was found in all social classes and at all levels of intelligence and was frequently based on the view that nothing worth while was done at ante-natal examina tions. Few mothers in either the study or the controf group said that they realized that ante-natal care was intended to safeguard the baby as well as themselves:

A subjective assessment was made of the adequacy of the mother's diet during pregnancy. Few mothers took vitamin supplements or iron preparations regularly. The diet was assessed as poor in 23 per cent. of the study group and 11 per cent. of the controls (Table VI, opposite).

TABLE V

PERCENTAGE DISTRIBUTION OF AGE OF MOTHER, PARITY AND SOCIAL CLASS STUDY AND CONTROL GROUPS, SALFORD, ENGLAND AND WALES, 1965

\begin{tabular}{|c|c|c|c|c|c|}
\hline \multirow{2}{*}{\multicolumn{2}{|c|}{ Particulars of Mother }} & \multirow{3}{*}{$\begin{array}{c}\text { Study Group } n=113 \\
12 \\
32 \\
23 \\
17 \\
10 \\
3\end{array}$} & \multirow{3}{*}{$\begin{array}{c}\text { Control Group } n=220 \\
11 \\
38 \\
27 \\
16 \\
7 \\
1\end{array}$} & \multicolumn{2}{|c|}{ All Maternities } \\
\hline & & & & \multirow{2}{*}{$\begin{array}{c}\text { Salford } n=3,087 \\
13 \\
35 \\
27 \\
15 \\
8 \\
2\end{array}$} & \multirow{2}{*}{\begin{tabular}{|c|} 
England and Wales \\
9 \\
32 \\
30 \\
17 \\
8 \\
2
\end{tabular}} \\
\hline Age (yrs) & $\begin{array}{r}-19 \\
20-24 \\
25-29 \\
30-34 \\
35-39 \\
40-44\end{array}$ & & & & \\
\hline Parity (a) & $\begin{array}{l}0 \\
1 \\
2 \\
3 \\
4 \\
5 \\
5 \text { and over }\end{array}$ & $\begin{array}{r}36 \\
21 \\
16 \\
8 \\
8 \\
11\end{array}$ & $\begin{array}{r}31 \\
28 \\
19 \\
10 \\
5 \\
7\end{array}$ & $\begin{array}{r}31 \\
27 \\
20 \\
10 \\
6 \\
6\end{array}$ & $\begin{array}{r}35 \\
31 \\
17 \\
8 \\
4 \\
4\end{array}$ \\
\hline Social Class & $\begin{array}{l}\text { I, II, and III (non-manual) } \\
\text { III (manual) } \\
\text { IV } \\
\text { V } \\
\text { Illegitimate } \\
\text { Unclassified/Unknown }\end{array}$ & $\begin{array}{r}6 \\
40 \\
20 \\
20 \\
12 \\
2\end{array}$ & $\begin{array}{r}10 \\
42 \\
16 \\
15 \\
11 \\
7\end{array}$ & $\begin{array}{r}10 \\
38 \\
18 \\
15 \\
12 \\
8\end{array}$ & $\begin{array}{l}\bar{z} \\
\bar{z}\end{array}$ \\
\hline
\end{tabular}

(a) Legitimate maternities only. 
TABLE VI

SOCIAL FACTORS PRESENT IN STUDY AND CONTROL GROUPS (FIGURES ARE PERCENTAGES)

\begin{tabular}{l|c|c}
\hline \multicolumn{1}{c|}{ Factor } & $\begin{array}{c}\text { Study } \\
\text { Group } \\
n=113\end{array}$ & $\begin{array}{c}\text { Control } \\
\text { Group } \\
n=209\end{array}$ \\
\hline $\begin{array}{l}\text { Mothers thought only limited ante-natal } \\
\text { care necessary }\end{array}$ & $19 *$ & 7 \\
Mother's diet considered poor & $23 *$ & 11 \\
Family shared house with relatives & 18 & 11 \\
Family seen less often than once a week & 62 & 19 \\
Both parents from local families & 16 & 16 \\
Neither parents from local families & $34 *$ & 19 \\
Family problems present & $27 \dagger$ & 38 \\
Attended clinic before 16 weeks & 76 & 72 \\
Attended family doctor before 16 weeks & & \\
\hline
\end{tabular}

- $0.01>P>0.001$ difference significant at 1 per cent. level. $+0.05>P>0.02$ difference significant at 5 per cent. level.

\section{Family Circumstances}

These were examined because it was felt that families isolated from relatives might find it difficult to obtain practical help during the pregnancy or advice on minor problems. Table VI shows that there was little difference between the study group and the control group. More of the study families than the controls shared a house with relatives and this was particularly noticeable in Social Classes IV and V. Of those who shared a house and lost a baby, two-thirds were having their first baby and 45 per cent. were under the age of 20.

However, few mothers said that they had any difficulty in getting to a clinic because of distance, unsuitability of transport, or through having to take young children with them.

\section{Family Problems}

The problems looked for were principally those within the immediate family, and included desertion, marital disharmony, problems of provision (father unemployed or with an unstable work record, financial or housing difficulties, etc.), and chronic illness, either physical or mental. Illegitimacy was not by itself regarded as a problem, nor was it enough to find that a family was on a "problem family register". Information was obtained both from the interview and from available records. Table VI shows that the proportion with problems was nearly twice as great in the study group as in the controls.

Early in the study, the health visitor was impressed by the number of husbands who were not at work at the time of her interview with the mothers, but after making allowances for those on shift work or self-employed the proportions in the study group and control group were about the same-between 15 and 20 per cent.
Attendance for Ante-natal Care

Butler and Bonham (1963) excluded visits to a doctor for confirmation of pregnancy from their discussion of the stage at which ante-natal care started, and showed that 49 per cent. of mothers booked for their confinement before the 16th week of pregancy. In the present study the stage of pregnancy at which the mother visited her doctor for the first time has been kept separate from the date on which she booked for her confinement by attending a hospital or local authority clinic. This latter date seems comparable to that used by Butler and Bonham.

In Salford only 27 per cent. of the study group and 38 per cent. of the controls had booked by the 16th week, but 76 per cent. of the study group and 72 per cent. of the controls said they had consulted their doctors by this stage (Table VI). It was not possible to confirm these latter statements from the records. 8 per cent. of the study group and 6 per cent. of the controls had not been to their doctor by the 24th week; the proportions not booked at a clinic by this stage were 35 and 24 respectively.

The stage of pregnancy at which the mothers went to their doctor for confirmation of pregnancy was examined in relation to the mother's attitude to ante-natal care and the presence or absence of family problems (Table VII). In both the study and control groups an unfavourable finding in relation to either of these factors was associated with a reduced proportion seeing their doctor before the 16 th week. In the small group of ten mothers who had both factors present, not one had seen her doctor by this stage. Surprisingly, however, the women who lost their babies more often saw their doctor before the 16th week, and this advantage is present in almost all the sub-groups of Table VII (overleaf).

The delay between confirmation of pregnancy and booking for ante-natal care is further examined in Table VIII (overleaf).

When compared with the control group, delay among mothers who lost their babies most often exceeded 8 weeks in what might be thought the least likely group-those with no problems and a good attitude to care. Twelve of the 24 study mothers involved conceived before marriage, had their pregnancies confirmed, and then did not receive further care until the 4th or 5th month. Another six attended very early in pregnancy and neither doctor nor mother thought further care necessary until the 4th month. Delay is generally least in the control group, but it is disturbing that as many as one-third delayed for 2 months or more between seeing their family doctor and attending a clinic. During this time very few of them returned to their own doctor for examination. 
TABLE VII

FIRST VISIT TO FAMILY DOCTOR RELATED TO PRESENCE OF FAMILY PROBLEMS AND MOTHER'S ATTITUDE TO ANTE-NATAL CARE

\begin{tabular}{|c|c|c|c|c|c|c|c|}
\hline \multirow{3}{*}{ Problems } & \multirow{3}{*}{$\begin{array}{l}\text { Mother's Attitude to } \\
\text { Ante-natal Care }\end{array}$} & \multicolumn{3}{|c|}{ Study Group } & \multicolumn{3}{|c|}{ Control Group } \\
\hline & & \multirow{2}{*}{$\begin{array}{l}\text { Total } \\
\text { Number }\end{array}$} & \multicolumn{2}{|c|}{$\begin{array}{l}\text { Attending doctor } \\
\text { before } 16 \text { weeks }\end{array}$} & \multirow{2}{*}{$\begin{array}{c}\text { Total } \\
\text { Number }\end{array}$} & \multicolumn{2}{|c|}{$\begin{array}{l}\text { Attending doctor } \\
\text { before } 16 \text { weeks }\end{array}$} \\
\hline & & & No. & Per cent. & & No. & Per cent. \\
\hline None present & $\begin{array}{l}\text { Good } \\
\text { Poor } \\
\text { All mothers }\end{array}$ & $\begin{array}{l}52 \\
12 \\
64\end{array}$ & $\begin{array}{r}46 \\
9 \\
55\end{array}$ & $\begin{array}{l}88 \\
75 \\
86\end{array}$ & $\begin{array}{r}167 \\
9 \\
176\end{array}$ & $\begin{array}{r}125 \\
6 \\
131\end{array}$ & $\begin{array}{l}75 \\
67 \\
74\end{array}$ \\
\hline Present & $\begin{array}{l}\text { Good } \\
\text { Poor } \\
\text { All mothers }\end{array}$ & $\begin{array}{r}26 \\
7 \\
33\end{array}$ & $\begin{array}{r}19 \\
0 \\
19\end{array}$ & $\begin{array}{r}73 \\
0 \\
58\end{array}$ & $\begin{array}{r}30 \\
3 \\
33\end{array}$ & $\begin{array}{r}19 \\
0 \\
19\end{array}$ & $\begin{array}{r}63 \\
0 \\
58\end{array}$ \\
\hline All Mothers & $\begin{array}{l}\text { Good } \\
\text { Poor } \\
\text { All mothers* }\end{array}$ & $\begin{array}{l}78 \\
19 \\
97\end{array}$ & $\begin{array}{r}65 \\
9 \\
74\end{array}$ & $\begin{array}{l}83 \\
47 \\
76\end{array}$ & $\begin{array}{r}197 \\
12 \\
209\end{array}$ & $\begin{array}{r}144 \\
6 \\
150\end{array}$ & $\begin{array}{l}73 \\
50 \\
72\end{array}$ \\
\hline
\end{tabular}

*Omitted from Study Group-Not interviewed 14, Incomplete data 2.

*Omitted from Control Group-Not interviewed 11.

TABLE VIII

DELAY BETWEEN FIRST VISIT TO FAMILY DOCTOR AND ATTENDANCE AT CLINIC RELATED TO PRESENCE OF FAMILY PROBLEMS AND MOTHER'S ATTITUDE TO ANTE-NATAL CARE

\begin{tabular}{|c|c|c|c|c|c|c|c|}
\hline \multirow{3}{*}{ Problems } & \multirow{3}{*}{$\begin{array}{l}\text { Mother's Attitude to } \\
\text { Ante-natal Care }\end{array}$} & \multicolumn{3}{|c|}{ Study Group } & \multicolumn{3}{|c|}{ Control Group } \\
\hline & & \multirow{2}{*}{$\begin{array}{l}\text { Total } \\
\text { Number }\end{array}$} & \multicolumn{2}{|c|}{$\begin{array}{c}\text { Delay of } \\
8 \text { weeks or more }\end{array}$} & \multirow{2}{*}{$\begin{array}{l}\text { Total } \\
\text { Number }\end{array}$} & \multicolumn{2}{|c|}{$\begin{array}{c}\text { Delay of } \\
8 \text { weeks or more }\end{array}$} \\
\hline & & & No. & Per cent. & & No. & Per cent. \\
\hline None & $\begin{array}{l}\text { Good } \\
\text { Poor } \\
\text { All mothers }\end{array}$ & $\begin{array}{l}52 \\
12 \\
64\end{array}$ & $\begin{array}{r}24 \\
4 \\
28\end{array}$ & $\begin{array}{l}46 \\
33 \\
44\end{array}$ & $\begin{array}{r}167 \\
9 \\
176\end{array}$ & $\begin{array}{r}46 \\
5 \\
51\end{array}$ & $\begin{array}{l}28 \\
56 \\
29\end{array}$ \\
\hline Present & $\begin{array}{l}\text { Good } \\
\text { Poor } \\
\text { All mothers }\end{array}$ & $\begin{array}{r}23 \\
7 \\
30\end{array}$ & $\begin{array}{r}13 \\
2 \\
15\end{array}$ & $\begin{array}{l}56 \\
29 \\
50\end{array}$ & $\begin{array}{r}30 \\
3 \\
33\end{array}$ & $\begin{array}{r}16 \\
0 \\
16\end{array}$ & $\begin{array}{r}53 \\
0 \\
48\end{array}$ \\
\hline All Mothers & $\begin{array}{l}\text { Good } \\
\text { Poor } \\
\text { All mothers* }\end{array}$ & $\begin{array}{l}75 \\
19 \\
94\end{array}$ & $\begin{array}{r}37 \\
6 \\
43\end{array}$ & $\begin{array}{l}49 \\
32 \\
46\end{array}$ & $\begin{array}{r}197 \\
12 \\
209\end{array}$ & $\begin{array}{r}62 \\
5 \\
67\end{array}$ & $\begin{array}{l}32 \\
42 \\
32\end{array}$ \\
\hline
\end{tabular}

*Omitted from Study Group-Not interviewed 14, Incomplete data 5.

*Omitted from Control Group-Not interviewed 11.

High Risk Cases and Home Booking

Criteria indicating the desirability of hospital delivery include late maternal age, primiparity, and multiparity. Of the 113 mothers who lost infants, 29 ( 26 per cent.) fell into high risk groups on age and parity grounds compared with 16 per cent. of the control group. Of the 29 in the study group, twelve (41 per cent.) were originally booked for home delivery (control group 42 per cent.) and another four cases were not booked at all. Table IX gives the circumstances in which these twelve bookings were made. The two mothers who were refused hospital delivery were both late in seeking care, and in the end only four of the group were confined at home. In half the cases the advisability of hospital confinement does not seem to have been discussed. 


\section{UNEXPLAINED DEATHS}

Previous reports (Baird, Walker, and Thomson, 1954; Fairweather, Russell, Anderson, Bird, Millar, and Pearcy, 1966) have shown that a considerable proportion of perinatal deaths occur without any satisfactory explanation. In the present study forty of the 115 ( 35 per cent.) fell into a group in which the underlying cause of death was obscure (premature labour, foetal anoxia, and cause unknown). These groups have been compared with two other groupsthose with congenital abnormalities and those with other well-defined pathological or obstetric conditions (Table X).

The unexplained groups as a whole were characterized by an indifferent attitude to ante-natal care and a poor diet; those mothers who had babies with congenital abnormalities closely resembled the control group, and those with other clearly-defined conditions occupied an intermediate position.

\section{TOXAEMIA}

Seventeen cases in which toxaemia was a major factor, fifteen of them stillbirths, were examined to see if avoidable factors were present. Four of them were originally booked for home confinement although one had had hypertension in her only other pregnancy, and one was having her fifth baby. Both of these mothers were first seen at the local authority clinic at the 7th month although one had seen her family doctor 3 months previously. All four were eventually delivered in hospital - being admitted as emergencies after the onset of antepartum haemorrhage (1 case) or the diagnosis of intrauterine death ( 3 cases).

Although seven of the cases (including the two live births) were admitted to hospital for short periods during the ante-natal period, there were another three mothers who were ill at home without having treatment. Two of them had been under hospital supervision from the 8th week of pregnancy.
Advice on diet and rest was ignored or misunderstood. In one case the mother, who had become pregnant within months of leaving school and married immediately after her 16th birthday, said she had had fits at home 2 weeks before delivery at the 34th week. In the second case the mother said she had serious headaches, sickness, and swelling of the ankles without seeking advice; and the third case was an 18-year-old ex-grammar school pupil who did not see any need for early care, ate a very poor diet, saw her family doctor at 22 weeks, and arrived at the hospital clinic at 28 weeks. She had delayed seeing her doctor because she was too ill at 4 months with sickness, headaches, and vaginal bleeding. She was not admitted to hospital before having an ante-partum haemorrhage at 37 weeks.

Five of the mothers went into labour when in the ante-natal ward; of the others, five had a sudden ante-partum haemorrhage (one while returning home from an ante-natal visit at the 33rd week), in five there was an intra-uterine death (two at or beyond term), and two went into spontaneous labour (at 34 and 41 weeks).

\section{Discussion}

One of the more interesting aspects of the present study has been the way the picture changes with the depth of the information. The registered causes of death tell one little, particularly since stillbirths and first week deaths are usually classified in a different way. Information from other available records adds more detail but, as Shegog (1966) has pointed out, the relevant records are widely dispersed and it takes considerable effort to collate them. This study has been an attempt to give the picture even more depth by hearing the mother's story, her attitudes, and her problems.

It is generally believed that early ante-natal care is important if only to provide a base-line for future observations. The importance of continuous care

TABLE X FACTORS PRESENT IN RELATION TO CAUSE OF PREMATURE DEATH (FIGURES ARE PERCENTAGES)

\begin{tabular}{|c|c|c|c|c|}
\hline \multirow{2}{*}{$\begin{array}{l}\text { Factor present in Relation to } \\
\text { cause of Premature Death }\end{array}$} & \multicolumn{4}{|c|}{ Pathological or Obstetric Condition } \\
\hline & $\begin{array}{l}\text { Premature Labour } \\
\qquad n=20\end{array}$ & $\begin{array}{c}\text { Anoxia and } \\
\text { Unknown } \\
n=20\end{array}$ & $\begin{array}{l}\text { Congenital } \\
\text { Abnormality } \\
n=21\end{array}$ & $\begin{array}{c}\text { All others } \\
n=54\end{array}$ \\
\hline $\begin{array}{l}\text { First visit to doctor before } 16 \text { weeks } \\
\text { First visit to clinic before } 16 \text { weeks } \\
\text { Mother's diet considered poor } \\
\text { Mother thought only limited ante-natal care necessary } \\
\text { Parous women with history of stillbirth, infant death, } \\
\text { or living premature infant } \\
\text { Family problems present }\end{array}$ & $\begin{array}{c}63 \\
15 \\
33 \\
38 \\
\\
8 \\
(n=12) \\
28\end{array}$ & $\begin{array}{c}77 \\
32 \\
40 \\
20 \\
36 \\
(n=11) \\
27\end{array}$ & $\begin{array}{c}88 \\
19 \\
12 \\
6 \\
44 \\
(n=9) \\
35\end{array}$ & $\begin{array}{c}76 \\
33 \\
19 \\
17 \\
53 \\
(n=36) \\
38\end{array}$ \\
\hline
\end{tabular}

Note-Percentages have been calculated in respect of the number of cases in which information about the relevant factor was available. 
from an early stage of pregnancy is emphasized by the short gestation period of many perinatal deaths. Since only the live births among those born before the end of the 28th week are counted among the perinatal deaths the importance of early morbidity is understated in these data. There may be a case for extending the registration of stillbirths to include babies born dead after 20 weeks gestation. In New York City, for example, where such a rule applies, 45 per cent. of the foetal deaths registered after the 20 th week, occurred in the gestation period 20 to 27 weeks (New York, 1964).

Approximately three-quarters of all the mothers saw their family doctor before the 16th week of pregnancy and at that stage there was little difference between the mothers who later had perinatal deaths and those in the control group. It is at the next stage, that of making definite arrangements for confinement, that a significant difference appears between the two groups. Many of the mothers who delayed had had previous pregnancies during which they gained the impression that there is no value in ante-natal care. They supported their arguments from their experience with complaints of long waits, rushed examinations, and an impersonal approach which did not encourage them to ask questions or seek advice.

In most cases the family doctor could probably do more to plan the course of care and to ensure that this course is followed. He would obviously be helped in this by close contact with a midwife and health visitor. Social problems in the general family situation were shown to affect the acceptance of ante-natal care by the mother, and are a further reason for the involvement of many different workers during this period.

In many of the circumstances leading to perinatal death, good ante-natal care is as important as hospital delivery. Indeed, hospital booking may produce a situation in which the mother feels that she cannot face up to the visit and delays her first attendance, where there is no follow-up of those not attending and she feels unable to ask questions. About onequarter of all the mothers said that at times they did not feel well enough to travel far from home and, in addition, thought that once having booked for a hospital delivery, routine or emergency care could no longer be expected from the family doctor.

Toxaemia is an important factor in perinatal deaths, and several shortcomings in its control have been shown in this study. Mothers do not always appreciate the seriousness of symptoms and may not mention them unless asked. They often do not understand advice about diet or rest, or may claim that no such advice has been given. It is not enough to tell a mother that her blood pressure is raised and expect her to understand the implications. The difficulty in communication, particularly in a busy hospital clinic, is well known (Cartwright, 1964; McGhee, 1961), and close co-operation between the hospital and domiciliary services may be necessary, so that mothers can be visited at home and their problems be discussed in quieter, accustomed surroundings.

\section{SUMmaRY}

The perinatal deaths which occurred in Salford in 1965 have been studied from records and by interviews. Particular attention was paid to social factors and these were compared with those of a control group.

Mothers who lost a baby in the perinatal period were more likely, when compared with the control group, to have a poor attitude to antenatal care, to have a poor diet, to have serious family problems and to delay before booking for ante-natal care even though they had seen a doctor for confirmation of pregnancy at an early stage.

A high proportion of the mothers were booked fof hospital confinement and attended hospital for ante-natal care, but in a number of cases ignorance, apathy, and misunderstanding led to inadequate care. More positive action on the part of the maternity services is suggested.

This study would not have been possible without the encouragement and co-operation of a large number of people. Records were made available by many local obstetricians, paediatricians, pathologists, and general practitioners, and by midwives and health visitors of the local health authority. The interviews of the control mothers were carried out by a number of health visitors, but all the study group were interviewed by Mrs. Joy Fawcett.

Particular thanks are due to Dr J. L. Burn, Medical Officer of Health for the City of Salford, who suggested the study, and to my colleagues Professor Alwyn Smith, Dr A. M. Adelstein, Dr T. Fryers, and Dr Joyce Leeson for criticism and advice.

\section{REFERENCES}

Baird, D., Walker, J., and Thomson, A. M. (1954). J. Obstet. Gynaec. Brit. Emp., 61, 433 (The causes and prevention of stillbirths and first week deaths. Part III: A classification of deaths by clinical cause: the effect of age, parity and length of gestation on death rates by cause). 
Butler, N. R., and Bonham, D. G. (1963). "Perinatal Mortality'. Livingstone, Edinburgh and London.

Cartwright, Ann (1964). "Human Relations and Hospital Care". Routledge and Kegan Paul, London.

Daly, C., Heady, J. A., and Morris, J. N. (1955). Lancet, 1, 445 (Social and biological factors in infant mortality. III. The effect of mother's age and parity on socialclass differences in infant mortality).

Fairweather, D. V. I., Russell, J. K., Anderson, G. S., Bird, T., Millar, D. G., and Pearcy, P. A. M. (1966). Lancet, 1, 140 (Perinatal mortality in Newcastle upon Tyne, 1960-62).

Feldstein, M. S., and Butler, N. R. (1965). Brit. J. prev. soc. Med., 19, 128 (Analysis of factors affecting perinatal mortality).

Hobbs, M. S. T., and Acheson, E. D. (1966). Brit. med.J., 1, 499 (Perinatal mortality and the organisation of obstetric services in the Oxford area in 1962).

Illsley, R., and Kincaid, J. C. (1963). In "Perinatal Mortality" (edited by Butler, N. R., and Bonham, D. G.), Section K, p. 270. Livingstone, Edinburgh and London.

Kincaid, J. C. (1965). Brit. med. J., 1, 1057 (Social pathology of foetal and infant loss).
McGhee, Anne (1961). "The Patient's Attitude to Nursing Care". Livingstone, Edinburgh and London.

Ministry of Health (1966). "Report on Confidential Enquiries into Maternal Deaths in England and Wales 1961-1963". Reports on Public Health and Medical Subjects, No. 115. H.M.S.O., London.

Morris, J. N., and Heady, J. A. (1955). Lancet, 1, 554 (Social and biological factors in infant mortality. V. Mortality in relation to the father's occupation 1911-1950).

New York, City of (1964). "Vital Statistics 1956 to 1963". Department of Health, City of New York, New York.

Shegog, R. (1966). In "Problems and Progress in Medical Care. Second Series", ed. G. McLachlan, p. 251 [Nuffield Provincial Hospitals Trust]. Oxford University Press, London.

Spicer, C. C., and Lipworth, L. (1966). "Regional and Social Factors in Infant Mortality". General Register Office. Studies on Medical and Population Subjects. No. 19. H.M.S.O., London.

Titmuss, R. M. (1943). "Birth, Poverty and Wealth". Hamish Hamilton, London. 